УДК 57(092) Лихолат

doi:10.25128/2078-2357.19.1.21

${ }^{1}$ С.В. ПИДА, ${ }^{2}$ І.П. ГРИГОРЮК, ${ }^{1}$ М.М. БАРНА

${ }^{1}$ Тернопільський національний педагогічний університет імені Володимира Гнатюка вул. М. Кривоноса, 2, Тернопіль, 46027

${ }^{2}$ Національний університет біоресурсів і природокористування України вул. Героїв оборони, 15. Київ, 03041

e-mail:pyda@chem-bio.com.ua

\title{
ЛИХОЛАТ ЮРІЙ ВАСИЛЬОВИЧ - ВІДОМИЙ УЧЕНИЙ-БІОЛОГ, НАСТАВНИК, ГРОМАДСЬКИЙ ДІЯЧ (до 60-річчя від дня народження)
}

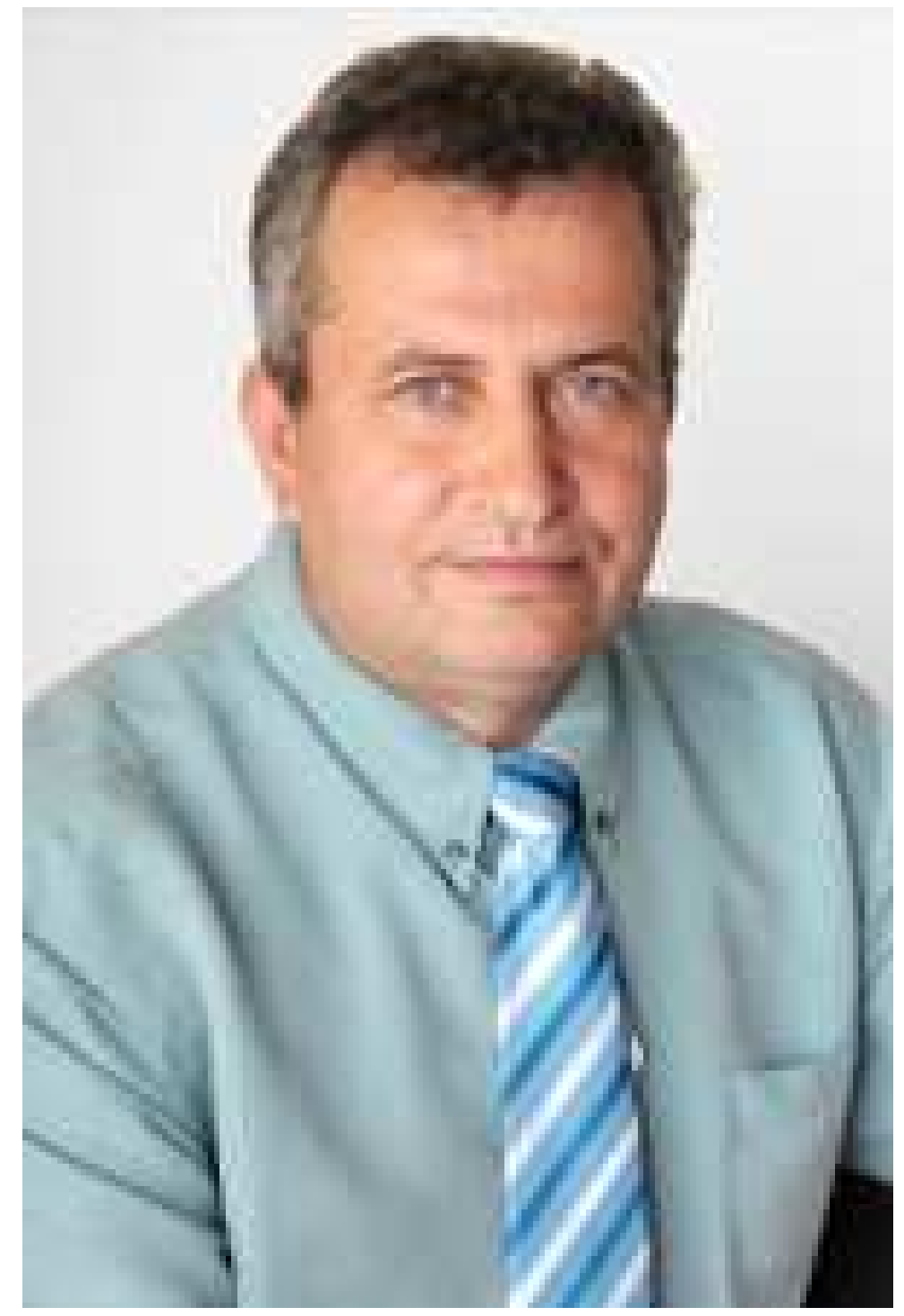

\section{ПРОФЕСОР ЮРІЙ ВАСИЛЬОВИЧ ЛИХОЛАТ}

«І я бачив, - нема чоловікові кращого, як ділами своїми радіти, бо це доля його!»

Еклезіаст, 3.22 
29 січня 2019 року виповнилося 60 років від дня народження подвижника біологічної науки, доктора біологічних наук, професора, академіка АН Вищої школи України, дійсного члена Міжнародної академії біоенерготехнологій, завідувача кафедри фізіології та інтродукції рослин Дніпровського національного університету імені Олеся Гончара Юрія Васильовича Лихолата.

Народився 29.01. 1959 р. у мальовничому селі Мишурин-Ріг Верхньодніпровського району Дніпропетровської області у сім’ї вчителя. У 1976-1981 рр. навчався на кафедрі геоботаніки Дніпропетровського державного університету (ДДУ). Крім навчання, Ю.В. Лихолат значну увагу приділяв студентській науковій роботі. Під керівництвом своїх наставників професорів О. Л Бельгарда, А. П. Травлєєва та доцента Тарасова В. В. у цей період досліджував біолого-екологічні властивості адвентивних видів Придніпровського регіону, значну увагу при цьому приділяючи виявленню масштабів їх розповсюдження та визначенню рівня їх $\beta$-радіоактивності.

Трудову діяльність Ю. В. Лихолат розпочав у 1981 р. після закінчення Дніпропетровського державного університету в радгоспі «Декоративні культури» м. Дніпропетровська. У цей період у місті відбувалося активне будівництво нових житлових масивів. Працюючи на посаді агронома радгоспу, під його керівництвом вирощували посадковий матеріал для проведення озеленення дніпропетровських масивів «Тополя-2», «Тополя-3», «Сокіл», «Сонячний», «Перемога» та реконструкції низки парків, скверів, проспектів і вулиць міста. У цей період Юрій Васильович також активно займався раціоналізаторською роботою. Так, у 1982 році він був визнаний кращим раціоналізатором області у системі зеленого будівництва.

31983 до 1986 рр. - аспірант кафедри фізіології рослин та екології ДДУ. Кандидатську дисертацію захистив у 1986 р. на тему «Водный режим растений в условиях загрязнения среды углеводородами» під керівництвом д.б.н., професора Долгової Л. Г. 31986 р. - асистент, а 3 1990 р. - доцент кафедри фізіології рослин ДДУ. У 1992-2000 pp. - заступник декана заочного факультету та заступник директора Інституту біології з заочної форми навчання. Доктор біологічних наук за спеціальністю "Екологія" - $з 2003$ р., професор - 32005 р. Докторську дисертацію «Еколого-фізіологічні основи формування дернових покривів в умовах степової зони України (стійкість, динаміка, техногенез)» захистив у Чернівецькому національному університеті імені Юрія Федьковича, науковий консультант д. б. н., професор І. І. Коршиков.

Його наукові інтереси пов'язані із сферою практичної екології. Напрямки наукових досліджень стосуються актуальних проблем розробки фізіолого-біохімічних теоретичних $\mathrm{i}$ практичних основ моделювання та формування стійких оптимізуючих середовище культурфітоценозів, основною складовою яких $є$ дерноутворюючі трави. Засновник нового наукового напрямку у біології - техногазоноведення.

На основі наукових розробок Ю.В. Лихолата у 90-х роках на території хімічних підприємств міста та області проведена реконструкція існуючих зелених насаджень. На початку 2000-х років наукові розробки враховані при реконструкції газонів на вулицях міста.

Поряд із цим, спільно із співробітниками Державного підприємства «Конструкторське бюро «Південне» ім. М. К. Янгеля» м. Дніпропетровська, проводив дослідження за напрямком корекції порушень фізіології розвитку біосистем у процесі розвитку біоенергетичних взаємодій внутрішнього та зовнішнього поля, використання мм-хвиль для підвищення ефективності біосистем, використання поля різної природи для компенсації впливу на фотосистеми негативних чинників космічних станцій. Особлива увага приділена технології використання мм-хвиль на різних стадіях вирощування рапсу для його використання в виробництві біопалива.

В останні роки під його керівництвом проведена інвентаризація парків міста Дніпро та розроблені заходи щодо проведення невідкладних заходів 3 їхнього оздоровлення та реконструкції.

Ю.В. Лихолат бере активну участь у «Програмі 3 локалізації та ліквідації амброзії полинолистої та інших карантинних організмів на території м. Дніпра», яка, зокрема, включає забезпечення реалізації комплексу заходів з локалізації розробки біологічних методів контролю та ліквідації вогнищ карантинних рослин і чисельності їх насіння на території міста,

166 ISSN 2078-2357. Наук. зап. Терноп. нац. пед. ун-ту. Сер. Біол., 2019, № 1 (75) 
зменшення кількості випадків захворювання на алергію серед населення, пов'язаних 3 цвітінням амброзії та інших карантинних рослин, посилення уваги широких верств населення до існуючої проблеми шляхом популяризації знань та роз'яснень щодо шкідливості бур'яну алергену, приведення в належний фітосанітарний та естетичний стан території міста, забезпечення контролю за виконанням заходів проти карантинного бур'яну підприємствами, організаціями та установами незалежно від форми власності і підпорядкування, посадовими особами та громадянами. За його керівництва проводяться розробки біологічних методів боротьби 3 амброзією полинолистою: алелопатичного впливу рослинних екстрактів на вегетативний і генеративний розвиток цього карантинного виду.

Являючись науковим консультантом ботанічного саду ДНУ імені Олеся Гончара, Ю.В. Лихолат дбає про його розвиток та перспективи. За ініціативи вченого ботанічний сад постійно поповнюється новими рослинами, які спочатку проходять період інтродукційного випробування, а відтак передаються місту та області для впровадження в систему озеленення.

Ю.В. Лихолат автор і співавтор понад 570 наукових і науково-методичних праць. Серед них 6 монографій (одна видана за кордоном), 11 публікацій у виданнях, що входять у наукометричну базу Scopus, 20 - Web of Science, 2 підручники, 11 навчально-методичних посібників з яких 3 з грифом МОН України, 16 навчально-методичних розробок, 5 методичних рекомендацій для виробництва. Серед навчальної літератури значною популярністю користуються підручники - Адаптація рослин до антропогенних чинників. - Вінниця : ТОВ «Нілан-ЛТД», 2017. 98 с. (співавт.); Популяційна антропологія. - Дніпро : РВВ ДНУ, 2018. 296 с. (співавт.) та посібники - Землеробство 3 основами агрохімії декоративних рослин. Дніпропетровськ : Вид-во Дніпропетровського університету, 1999. 72 с. (одноосібно); Ландшафтний фітодизайн. - Дніпропетровськ : Вид-во Дніпропетровського університету, 2012. 201 с. (співавтор); Анатомія рослин. Дніпропетровськ : Нова ідеологія, 2013. 115 с. (співавтор); Спецпрактикум з фізіології та біохімії рослин. - ФОП Середняк Т.К., 2014. 224 с. (співавтор) та ін.

Величезна та невичерпна працездатність дозволили йому зробити значний внесок у розвиток міждисциплінарних досліджень загальних та теоретичних проблем сучасної фізіології та інтродукції рослин, екології, охорони довкілля, просвітницьку роботу рідного міста та України.

Академік академії наук Вищої школи України, дійсний член Міжнародної академії біоенерготехнологій - він здійснює керівництво науковою роботою магістрів, аспірантів, здобувачів. $€$ членом двох спецрад із захисту докторських і кандидатських дисертацій за спеціальністю "Екологія" та “Фізіологія рослин і біотехнологія". Член редколегії 5 наукових журналів. Брав участь у розробці галузевого стандарту Вищої освіти України за ОКР Магістр 3 Фізіології рослин: «Фізіологія адаптацій рослин», «Фізіологія та екологія фотосинтезу», «Генетична інженерія та біотехнологія рослин», «Екофізіологія рослин», член експертної ради МОН України секції «Лісове та садово-паркове господарство».

Ю.В. Лихолат постійно впроваджує в навчальний процес найновітніші методи досліджень і на належному науково-методичному рівні викладає нормативні курси: “Фізіологія адаптацій рослин”, “Екофізіологія", "Екологія”, “Газонознавство”, "Методологія та організація наукових досліджень”.

За роки роботи в ДНУ підготував цілу плеяду фахівців-біологів, які сьогодні успішно працюють у різних галузях України.

Наукова і педагогічна діяльність Ю.В. Лихолата здобула заслужений резонанс як в Україні, так і за ï межами, його наукові погляди набули визнання та розвитку серед учених молодшого покоління. Йому притаманні чесність, порядність, людяність, активна громадська позиція у процесі розвитку вітчизняної науки.

За особистий внесок у розвиток біологічної науки він нагороджений грамотами та подяками МОН України, Дніпровського національного університету імені Олеся Гончара, Донецького національного університету міені Василя Стуса, міста, області, «Почесним знаком ЦК ДОСААФ» (1986 рік), медаллю «За вірну службу ДНУ» (2013 рік) та медаллю «25 років АН ВШ України» (2017 рік). 
Сердечно вітаємо Юрія Васильовича Лихолата зі славним 60-річчям від дня народження та бажаємо благополуччя, нових професійних перемог та висот! Нехай доля і надалі буде прихильною до Вас, даруючи незрадливу удачу, натхнення, вірних і надійних друзів, втілення задуманого та якомога більше щасливих днів, зігрітих щирістю почуттів. Хай примножиться творене Вами добро, а Ваші наукові ідеї знаходять втілення!

\section{S.V. Pyda, I.P. Hryhoriuk, N.N. Barna}

Ternopil Volodymyr Hnatiuk National Pedagogical University, Ukraine.

National University of Life and Environmental Sciences of Ukraine, Ukraine

YURII VASYLOVYCH LYKHOLAT - RENOWNED SCIENTIST, BIOLOGIST, MENTOR AND PUBLIC FIGURE (dedicated to 60th anniversary)

January 29th, 2019 marks the 60th birthday of Yurii Vasylovych Lykholat, a proponent of biological science, doctor of sciences, professor, academician of the Academy of Sciences of Ukraine, a member of the International Academy of Bioenergetics, the head of the Department of Physiology and Plant introduction of the Oles Honchar Dnipro National University.

In 1981 after graduating from Dnipropetrovsk State University (DDU) Yu. V.Lykholat landed his career at a state farm "Ornamental Plants" located in the city of Dnipropetrovsk. In 1982 he was recognized for his great contribution into the development of city greenery.

From 1983 to 1986 he was doing his postgraduate course at the Department of Plant Physiology and Ecology at the State University of Agriculture. In 1986 he defended his Ph.D. thesis entitled "Water regime of plants in conditions of pollution of the environment by hydrocarbons" supervised by Professor Dolgova L. G. In 1986 he was appointed an assistant, and in 1990 - an Associate Professor of the Department of Plant Physiology at DDU. From 1992 to 2000 he became a deputy dean of the Extramural Department and deputy director of distance learning at the Institute of Biology. In 2003 he was awarded a PhD degree, subject "Ecology", in 2005 he became a Professor. 2005 doctoral dissertation "Ecological and physiological bases of formation of turf cover in conditions

The Doctoral dissertation "Ecological and physiological foundations of formation of turf covers in the climate of the steppe zone of Ukraine (stability, dynamics, technogenesis)" was defended at the Yurii Fedkovych Chernivtsi National University, scientific supervisor Professor I. I. Korshykov.

His scientific interests cover the issues of practical ecology. The research studies deal with the development of physiological and biochemical, both theoretical and practical foundations of modeling and the formation of a stable optimizing environment for cultivated phytocenoses, the main component of which is turf herbs. Yu. Lykholat is considered as a founder of a new scientific direction in biology - techno-gasology.

$\mathrm{Yu}$. V. Lykholat is the author and co-author of more than 570 scientific and methodological works, including 6 monographs (one published abroad), 11 publications in Scopus, 20 - Web of Science, 2 textbooks, 11 textbooks, 3 of which authorized by the Ministry of Education and Science of Ukraine, 16 practical manuals, 5 methodical guidelines for manufacturing.

Надійшла 15.02.2019. 